\title{
Sources, Rates and Time of Nitrogen Application on Maize Crops under No-Tillage System
}

\author{
J. A. Souza, S. Buzetti, M. C. M. Teixeira Filho \& A. Moreira
}

To cite this article: J. A. Souza, S. Buzetti, M. C. M. Teixeira Filho \& A. Moreira (2016) Sources, Rates and Time of Nitrogen Application on Maize Crops under No-Tillage System, Communications in Soil Science and Plant Analysis, 47:19, 2200-2207, DOI: 10.1080/00103624.2016.1228948

To link to this article: https://doi.org/10.1080/00103624.2016.1228948

Accepted author version posted online: 16

Sep 2016.

Published online: 16 Sep 2016.

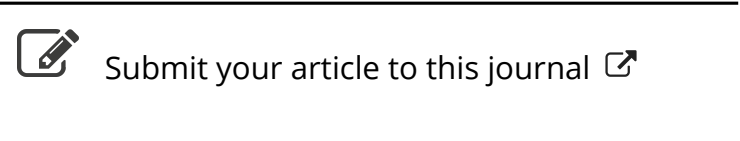

Џ Article views: 110

View Crossmark data ¿

Citing articles: 1 View citing articles $₫$ 


\title{
Sources, Rates and Time of Nitrogen Application on Maize Crops under No-Tillage System
}

\author{
J. A. Souza ${ }^{a}$, S. Buzetti ${ }^{b}$, M. C. M. Teixeira Filho ${ }^{b}$, and A. Moreira ${ }^{c}$ \\ ${ }^{a}$ Department of Crop Science, State University of Londrina, Londrina, Paraná State, Brazil; bDepartment of Crop \\ Science, São Paulo State University, Illha Solteira, São Paulo State, Brazil; 'Department of Soil Science, National \\ Soybean Research Center of the Empresa Brasileira de Pesquisa Agropecuária (EMBRAPA), Londrina, Paraná State, \\ Brazil
}

\begin{abstract}
Quantitatively, nitrogen $(\mathrm{N})$ is the foremost nutrient for maize crops (Zea mays L.), but the $\mathrm{N}$ source to increase the grain productivity still needs more investigation. Thus, the aim of this experiment was to study sources, rates and time of $\mathrm{N}$ application on the crop yield and agronomic characteristics of the maize under no-tillage system. The experiment was carried out during two growing seasons on an Oxisol under the factorial $5 \times 3 \times 3$ scheme with five $\mathrm{N}$ rates $\left(0,50,100,150\right.$, and $\left.200 \mathrm{~kg} \mathrm{ha}^{-1}\right)$ and three sources (ammonium-sulfatenitrate as inhibitor of the nitrification (ASN+I), ammonium sulfate (AS) and urea); we applied them two times with four replicates: first time at the sowing or later under side dressing when the plants had the six leaves stage. In the first year, the sources of $\mathrm{N}$ had no influence on the number of grain line /ear (NGLE), grain number/line (GNL), total number of grain/ear (TNFE), biomass of 100 grain, plant height (PH), height of the first ear insertion (AFEI) and stalk diameter, in contrast with the foliar $\mathrm{N}$ content and the crop yield. Early fertilization with $\mathrm{N}$ at the sowing time can afford applications as well as the total side dressing. The increase of the rates had positive influence on the $\mathrm{N}$ foliar content, plant height and 100 grains biomass. The highest productivities were found with rates above the threshold of $150 \mathrm{~kg} \mathrm{ha}^{-1}$, no matter the sources and the fertilization time.
\end{abstract}

\section{ARTICLE HISTORY}

Received 27 December 2015

Accepted 21 June 2016

\section{KEYWORDS}

Ammonium sulfate; ammonium sulfate nitrate; nitrogen fertilization; urea; Zea mays $\mathrm{L}$.

\section{Introduction}

Currently, studying the sources of nitrogen $(\mathrm{N})$ fertilization is still important because every fertilizer composition has a different performance in the soil as to the $\mathrm{N}$ losses by leaching or volatilization (Lara Cabezas, Kondörfer, and Motta 1997). These differences are results of several factors, such as the edaphoclimatic conditions, fertilizer composition and crop system (Fageria, Moreira, and Coelho 2011; Figueiredo et al. 2005).

Under no-tillage system (NTS), the $\mathrm{N}$ is applied on the soil surface, and this fact increases the losses by the volatilization of ammonia $\left(\mathrm{NH}_{3}{ }^{+}\right)$because the stover induce the fast hydrolysis of the fertilizer and make difficult to the planting system retain the $\mathrm{NH}_{3}{ }^{+}$(Lara Cabezas, Kondörfer, and Motta 1997). Thus, when the $\mathrm{N}$ source is the urea $(45 \%$ of $\mathrm{N})$, high rates of volatilization can be detected. One alternative to minimize these losses is to apply $\mathrm{N}$ acidic sources as the ammonium sulfate ( $20 \%$ of $\mathrm{N}$ ), but the ammonium $\left(\mathrm{NH}_{4}{ }^{+}\right)$will be susceptible to nitrification that make possible $\mathrm{N}$ losses in the system soil-plant because of nitrate leaching (Fageria 2014). Thus, these losses can be reduced by incorporating into the fertilizer composition some molecules that inhibit the $\mathrm{NH}_{4}{ }^{+}$nitrification such as ammonium sulfate-nitrate as one inhibitor of the nitrification. This mixture contain ammonium nitrate $\left(\mathrm{NH}_{4} \mathrm{NO}_{3}\right)$

CONTACT A. Moreira adonismoreira66@gmail.com E National Soybean Research Center of the Empresa Brasileira de Pesquisa Agropecuária (EMBRAPA), Rodovia Carlos João Strass, Acesso Orlando Amaral, Caixa Postal, 231, CEP 86001-970, Londrina County, Paraná State, Brazil. 
and ammonium sulfate with $26 \%$ of total $\mathrm{N}$ where $18.5 \%$ is ammonium, $7.5 \%$ is nitrate, but $22 \%$ is sulfur (S). This fertilizer still contains DMPP molecules (3, 4-dimethilpyrazole phosphate) to reduce the fast nitrification process and minimize the losses (IFA 2014).

The best time to apply $\mathrm{N}$ in maize crops may differ in every region, but it is usual to apply part of the $\mathrm{N}$ in the sowing time and the rest in topdressing when the plants have developed from 4 to 8 leaves (Pöttker and Wiethölter 2004). However, Lara Cabezas et al. (2005), after studying several years when the weather conditions were normal and the immobilizing activity of the soil biomass predominated, concluded that the early application of the $\mathrm{N}$ fertilization at pre-sowing conditions would improve the crop system. In contrast, extreme weather conditions would favor the side dressing application because of the immobilization by the stover, hydro stress and intense nitrification that is followed by nitrate leaching.

Furthermore, the $\mathrm{N}$ intake from mineral fertilizers reduces when the rate is increased because the supply is generally higher than the plant needs, and consequently losses are observed (Silva et al. 2006). Thus, among the factors that can reduce the crop yield is counted the mismanagement of the $\mathrm{N}$, uptake in higher quantity, and plant responses to higher crop yield. This experiment had the aim of studying sources, time of application and $\mathrm{N}$ rates on the grain yield and agronomic traits of maize under no tillage system.

\section{Material and methods}

\section{Site}

The experiment was carried out at the São Paulo State University (UNESP), in the Selviria County, Mato Grosso do Sul State, in Brazil (20 $22^{\prime}$ SL, $\left.51^{\circ} 22^{\prime} \mathrm{WL}\right)$. The soil classified as Oxisol, clay texture (Embrapa 2006) had been occupied by the native 'Savanna' vegetation and later on by annual crops as rice (Oryza sativa L.), wheat (Triticum aestivum L.), maize (Zea mays L.), and soybean (Glycine $\max$ L. Merrill). Based on the Köppen classification, the weather conditions is Aw: tropical humidity with rainy season in the summer and dry winter. The average annual temperature is $23.5^{\circ} \mathrm{C}$, the mean annual rainfall is $1370 \mathrm{~mm}$ and relative humidity of the air ranges from $70 \%$ to $80 \%$, and these values during the experimental time are seen in Figure 1.

\section{Experimental design, soil chemical characteristic and fertilization}

The experimental design was completely randomized blocks with four replicates under the factorial $5 \times 3 \times 2$ where we applied five $\mathrm{N}$ rates $\left(0,50,100,150\right.$ and $\left.200 \mathrm{~kg} \mathrm{ha}^{-1}\right)$ and three $\mathrm{N}$ sources ([ammonium-sulfate-nitrate as inhibitor of the nitrification (ASN+I), ammonium sulfate, and urea], applied two times (seed sowing or topdressing when the plants had six leaves completely expanded). In both growing seasons, the plots had $5.0 \mathrm{~m}$ in the useful length plus $2.0 \mathrm{~m}$ of border line where we sowed 5.0 seeds $0.20 \mathrm{~m}$ apart in 4.0 lines spaced $0.90 \mathrm{~m}$. The soil chemical analysis in the first $0.20 \mathrm{~m}$ followed the methods recommended by Raij et al. (2001): available phosphorus (P) (resin extractant $)=31 \mathrm{mg} \mathrm{kg}^{-1}, \mathrm{~S}=18 \mathrm{mg} \mathrm{kg}^{-1}$; soil organic matter $(\mathrm{SOM})=34 \mathrm{~g} \mathrm{~kg}^{-1}, \mathrm{pH}$ calcium chloride $\left(\mathrm{CaCl}_{2}\right)=5,0$, exchangeable potassium $\left(\mathrm{K}^{+}\right)=4.3 \mathrm{mmol}_{\mathrm{c}} \mathrm{kg}^{-1}$, exchangeable calcium $\left(\mathrm{Ca}^{2+}\right)=19.0 \mathrm{mmol}_{\mathrm{c}} \mathrm{kg}^{-1}$, exchangeable magnesium $\left(\mathrm{Mg}^{2+}\right)=12.0 \mathrm{mmol}_{\mathrm{c}} \mathrm{kg}^{-1}$, potential acidity hydrogen and aluminum $\left(\mathrm{H}^{+}+\mathrm{Al}^{3+}\right)=40.0 \mathrm{mmol}_{\mathrm{c}} \mathrm{kg}^{-1}$, cation exchange capacity $(\mathrm{CEC})=75.3 \mathrm{mmol}_{\mathrm{c}}$ $\mathrm{kg}^{-1}$, and base saturation $(\mathrm{V})=47 \%$. We calculated the fertilization following Cantarella, van Raij, and Camargo (1997) for maize crops. All the treatments had phosphorus pentoxide $\left(\mathrm{P}_{2} \mathrm{O}_{5}\right)$ at $70 \mathrm{~kg} \mathrm{ha}^{-1}$ as single superphosphate (SSP with $20 \%$ de $\left.\mathrm{P}_{2} \mathrm{O}_{5}\right)$ and potassium oxide $\left(\mathrm{K}_{2} \mathrm{O}\right)$ at $40 \mathrm{~kg} \mathrm{ha}^{-1}$ as potassium chloride ( $\mathrm{KCl}$ with $60 \%$ of $\mathrm{K}_{2} \mathrm{O}$ ) applied into the planting line. In both growing season, the experiment was carried out in area with nine years of non-tillage system (NTS), desiccated with glyphosate (1500 $\mathrm{g} \mathrm{ha}^{-1}$ a.i.) where the single hybrid AG $8088^{\circ}$ were sowed. The area was irrigated with $14 \mathrm{~mm}$ of water for uniform seed germination using the facilities of one central pivot where the time to emergence ranged from 5 to 7 days. 


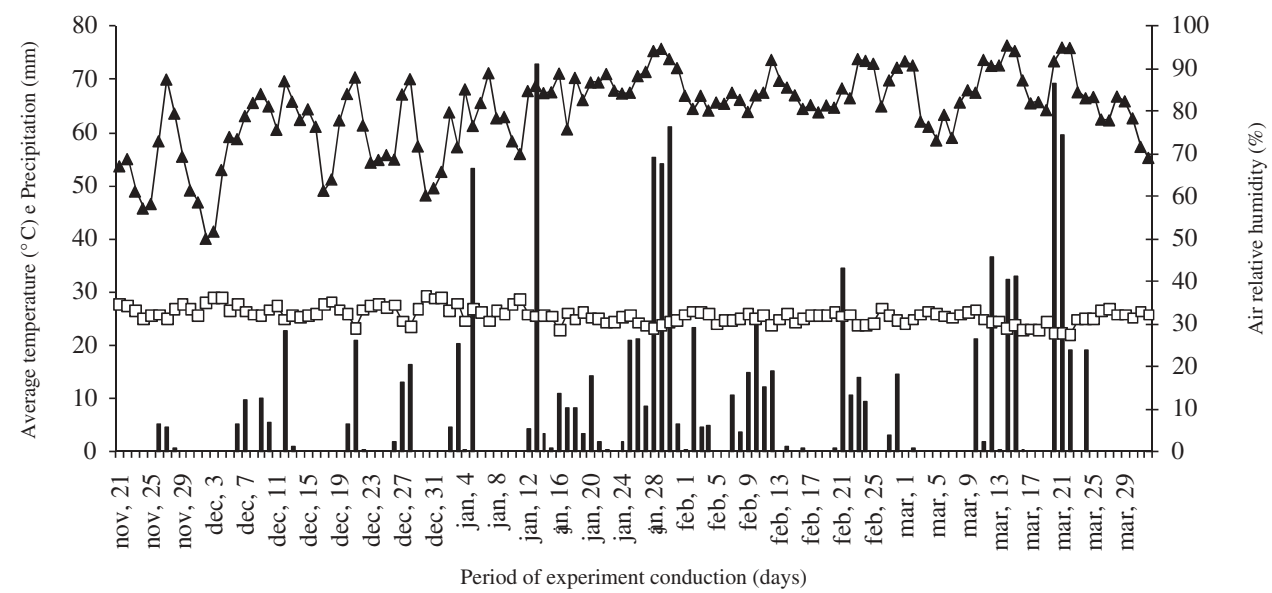

(A)

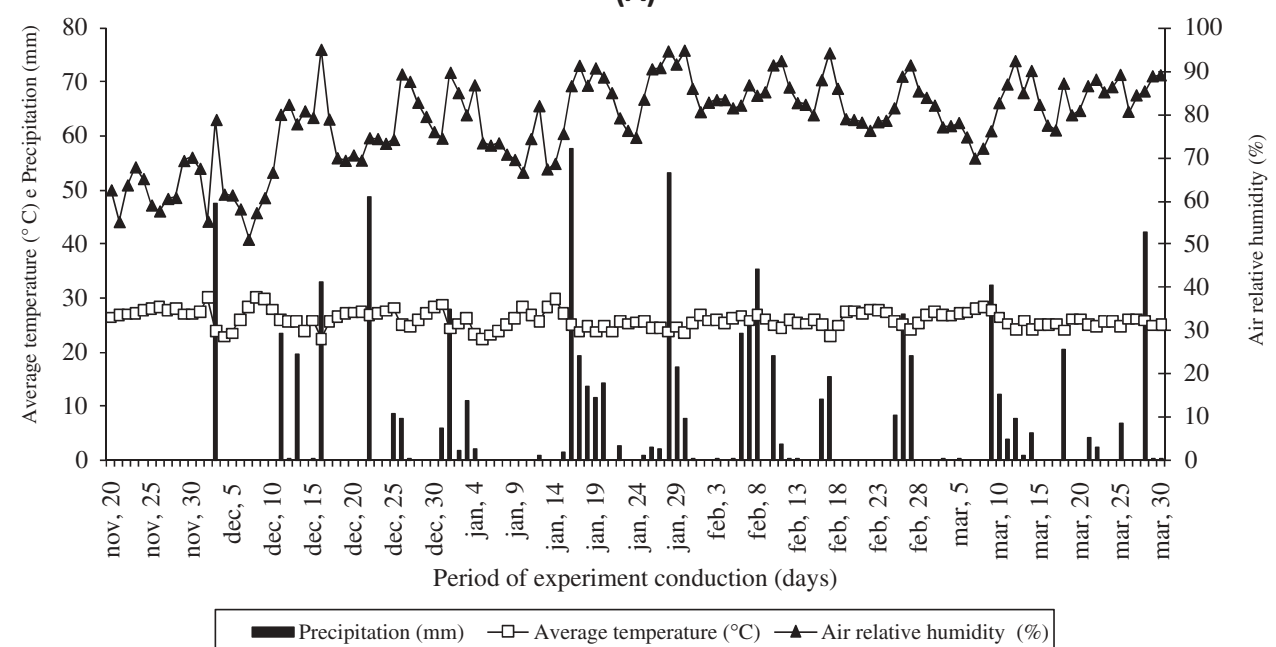

(B)

Figure 1. Rainfall $(\mathrm{mm})$, mean temperature $\left({ }^{\circ} \mathrm{C}\right)$ and relative humidity $(\%)$ during the experimental time in Selvíria-MS, growing season 1 (A) and growing season 2 (B).

\section{Area management, treatment application and foliar analysis}

The $\mathrm{N}$ fertilization was carried out soon after the seed sowing, applying the fertilizer close to the planting line (the usual $5.0 \mathrm{~cm}$ ), based on the $\mathrm{N}$ treatments applied in the crops. The side dressing $\mathrm{N}$ fertilization was carried out in the stage of six expanded leaves applying the fertilizer in between the lines, $0.20 \mathrm{~m}$ apart the crop line based on the plot treatments which did not is fertilized in the sowing time. After the fertilization, the area was irrigated by spraying water to minimize the $\mathrm{N}$ losses through volatilization of the $\mathrm{NH}_{3}{ }^{+}$because of the hydrolysis. This operation is usual in irrigated systems of grain yield when this fertilizer is applied.

The weed was managed through the post-emergence application of the herbicides atrazine + nicosulfuron $\left(3.5 \mathrm{~kg} \mathrm{ha}^{-1}+1.25 \mathrm{~L} \mathrm{ha}^{-1}\right.$ a.i.). The caterpillar was controlled by the mixture spinosad + triflumurom $\left(36.0+24.0 \mathrm{~g} \mathrm{ha}^{-1}\right.$ a. i.). When necessary, the supply of water followed a dosage of $14.0 \mathrm{~mm}$ in three days intervals using a fixed system of central pivot to irrigate the plots. The time to maize harvesting was 125 days after the emergence. 
At flowering, we collected at the base of the ears 20 leaves to evaluate the $\mathrm{N}$ content (Cantarella, van Raij, and Camargo 1997). One week before the harvesting, we measured the plant height (PH), ear height insertion and stalk diameter at the second inter-node of the plants. At the harvesting, the useful area of the every plot had five ears collected at random to counting the number of grain lines/ears (NGLE), number of grain/lines (NGL), total number of grain/ears (TNGE), and the biomass of 100 grains using an analytical scale. The water content of the grain was corrected to $13.0 \%$ (humid base). The grain yield was determined by collecting plants in the useful area (two central lines) from every plot. Thereafter, the grain weight had the estimates reported in $\mathrm{kg} \mathrm{ha}^{-1}$.

\section{Statistical analysis}

The data set were analyzed by the analysis of variance (ANOVA), F-test, and the means discriminated by the Tukey test at $5.0 \%$ of probability level for the $\mathrm{N}$ sources effects and time of application, and regression models $(P \geq 0.05)$ were fit to data from the $\mathrm{N}$ rates.

\section{Results and discussion}

\section{Foliar content of $\mathbf{N}$}

In both growing seasons, the $\mathrm{N}$ rates had influence on the $\mathrm{N}$ foliar content following a quadratic linear model with the highest $\mathrm{N}$ rates estimated in 176 and $214 \mathrm{~kg} \mathrm{ha}^{-1}$, respectively (Table 1). These responses are similar to Souza et al. (2011) who reported N rates from 170 to $196 \mathrm{~kg} \mathrm{ha}^{-1}$ in a similar study for two crops. Time of application had no influence in the $\mathrm{N}$ contents in both growing seasons. In contrast with Silva et al. (2005a), when the rates were also studied under the NTS, the highest content of N foliar was found when the whole $\mathrm{N}$ was applied in the stages from 4 to 6 leaves unlike the application in the sowing time. Based on the $\mathrm{N}$ sources, we found significant differences just in the first growing season when the AS induced higher $\mathrm{N}$ content in the leaves (Table 1). This result is corroborated by Lourente et al. (2007) and Pissinatti et al. (2013) who found higher increase in the $\mathrm{N}$ content when they applied AS than urea. In the first growing season, only the control had the content of $\mathrm{N}$ lower than the range from 27.0 to $35.0 \mathrm{~g} \mathrm{~kg}^{-1}$, and in the second growing season all of the treatments had the $\mathrm{N}$ contents lower than the best estimates for maize crops (Cantarella, van Raij, and Camargo 1997).

Table 1. Means of sources and $\mathrm{N}$ rates, and regression models of the foliar $\mathrm{N}$ content, plant height (PH), height of ear insertion (AIE) and stalk diameter (SD) of maize under no-tillage system.

\begin{tabular}{|c|c|c|c|c|c|c|c|c|}
\hline \multirow[b]{2}{*}{ Sources of $\mathrm{N}$} & \multicolumn{2}{|c|}{$\mathrm{N}\left(\mathrm{g} \mathrm{kg}^{-1}\right)$} & \multicolumn{2}{|c|}{$\mathrm{PH}(\mathrm{m})$} & \multicolumn{2}{|c|}{ AIE (m) } & \multicolumn{2}{|c|}{$\mathrm{SD}(\mathrm{mm})$} \\
\hline & Crop 1 & Crop 2 & Crop 1 & Crop 2 & Crop 1 & Crop 2 & Crop 1 & Crop 2 \\
\hline SNA+I & $31.50 \mathrm{~b}$ & $24.20 a$ & $2.85 a$ & $2.90 \mathrm{a}$ & $1.30 \mathrm{a}$ & $1.20 \mathrm{a}$ & $23.06 a$ & $16.20 a$ \\
\hline SA & $33.65 a$ & $24.00 \mathrm{a}$ & $2.84 a$ & $2.95 a$ & $1.31 \mathrm{a}$ & $1.20 \mathrm{a}$ & $22.87 a$ & $15.85 \mathrm{a}$ \\
\hline Ureia & $30.70 \mathrm{~b}$ & $23.85 a$ & $2.85 \mathrm{a}$ & $2.95 a$ & $1.30 \mathrm{a}$ & $1.20 \mathrm{a}$ & $22.88 a$ & $15.75 \mathrm{a}$ \\
\hline$P \geq 0.05$ & 1.80 & 0.95 & 0.04 & 0.05 & 0.03 & 0.05 & 0.77 & 0.90 \\
\hline \multicolumn{9}{|l|}{ Time } \\
\hline Sowing & $31.60 a$ & $24.40 \mathrm{a}$ & $2.88 \mathrm{a}$ & $2.95 a$ & $1.32 \mathrm{a}$ & $1.20 \mathrm{a}$ & $23.45 a$ & $16.20 a$ \\
\hline Side dressing & $32.28 \mathrm{a}$ & $24.60 a$ & $2.81 \mathrm{~b}$ & $2.90 \mathrm{a}$ & $1.28 \mathrm{~b}$ & $1.20 a$ & $22.45 b$ & $15.65 a$ \\
\hline$P \geq 0.05$ & 1.22 & 0.64 & 0.05 & 0.05 & 0.02 & 0.03 & 0.50 & 0.60 \\
\hline \multicolumn{9}{|l|}{ Rates $\left(\mathrm{kg} \mathrm{ha}^{-1}\right)$} \\
\hline 0 & 23.10 & 20.60 & 2.78 & 2.90 & 1.28 & 1.20 & 22.82 & 15.15 \\
\hline 50 & 29.92 & 23.10 & 2.86 & 2.95 & 1.31 & 1.20 & 23.00 & 15.90 \\
\hline 100 & 35.63 & 24.75 & 2.84 & 2.97 & 1.29 & 1.20 & 22.92 & 15.70 \\
\hline 150 & 35.77 & 25.35 & 2.85 & 2.94 & 1.31 & 1.21 & 22.92 & 16.35 \\
\hline 200 & 35.27 & 26.25 & 2.89 & 2.96 & 1.32 & 1.22 & 23.02 & 16.60 \\
\hline Means & 31.94 & 24.02 & 2.85 & 2.93 & 1.30 & 1.20 & 22.95 & 15.93 \\
\hline CV (\%) & 10.50 & 7.40 & 2.55 & 2.60 & 4.60 & 5.70 & 6.30 & 10.40 \\
\hline$F$-test & * & * & * & * & ns & ns & ns & * \\
\hline
\end{tabular}

*Significant at $5.0 \%$ of probability level. ${ }^{\text {ns }}$ not significant. Means followed by similar letter in the column are not different by the Tukey. 


\section{Components of grain yield}

In both growing seasons, the plant height and the insertion of ears, as well as the stalk diameter, had no influence from the $\mathrm{N}$ sources, but they were different as to the time of fertilizer application only in the first year when these components were more developed and the $\mathrm{N}$ was applied at the sowing time (Table 1). Likely, this fact was the result of the higher availability of the nutrient in the initial stages of the plants development. The plant responses show evidences that there was lower N supply from the soil in the first year than in the second. Santos et al. (2007) found that the N dosage or applying the whole $\mathrm{N}$ rate in the sowing time increased the plant height $(\mathrm{PH})$.

The $\mathrm{N}$ rates had influence on the $\mathrm{PH}$ following a crescent linear model in the first unlike the quadratic model in the second growing season when the highest height was found with the application of $\mathrm{N}$ at $136 \mathrm{~kg} \mathrm{ha}^{-1}$ (Table 1). The AFEI had no influence from rate increases, but the stalk diameter increased linearly in the second year. Increases in $\mathrm{PH}$ because of the $\mathrm{N}$ application in maize were also reported by Silva et al. (2005a), Gomes et al. (2007), Goes et al. (2013) and Kappes et al. (2014).

In both growing seasons, NRGE, and NGL were nonsignificant (Table 2) for sources and time of application as verified by Souza et al. (2011). By contrast, Sangoi, Ernani, and Silva (2007) verified that the total $\mathrm{N}$ application before or during the maize sowing reduced the TNGE while Lourente et al. (2007) verified that the urea did it because of the highest urea volatilization than the AS.

In both growing seasons, the increases in $\mathrm{N}$ rates also had no influence on the NRGE (Table 2). Souza et al. (2011) also did not find significant effect in the $\mathrm{N}$ rates on the NRGE. In the first growing season, however, there was linear increase on the NRGE and NGL. Silva et al. (2005a) found that the increase in the $\mathrm{N}$ rate had quadratic response on the NFGE, and TNGE as reported by Goes et al. (2013) for the TNGE. We highlight that genetic and environmental factors can have influence in these results (Baligar, Fageria, and He 2001).

Table 2. Means, Tukey test and regression models for number of grain lines/ears (NGLE), grain number/line (GNL), total number of grain/ear (TNGE), biomass of 100 grain and crop yield (GY) of maize under no-tillage system.

\begin{tabular}{|c|c|c|c|c|c|c|c|c|c|c|}
\hline \multirow[b]{2}{*}{ N Sources } & \multicolumn{2}{|c|}{ NGLE } & \multicolumn{2}{|c|}{ GNL } & \multicolumn{2}{|c|}{ TNGE } & \multicolumn{2}{|c|}{$\begin{array}{c}100 \\
\text { grains }(\mathrm{g})\end{array}$} & \multicolumn{2}{|c|}{$\begin{array}{c}\mathrm{GY} \\
\left(\mathrm{kg} \mathrm{ha}^{-1}\right)\end{array}$} \\
\hline & Crop 1 & Crop 2 & Crop 1 & Crop 2 & Crop 1 & Crop 2 & Crop 1 & Crop 2 & Crop 1 & Crop 2 \\
\hline SNA+I & $17.6 a$ & $17.3 a$ & $34.92 a$ & $34.50 a$ & $611.70 a$ & $593.00 \mathrm{a}$ & $26.50 a$ & $32.60 a$ & $8920 a$ & $10846 a$ \\
\hline SA & $17.3 a$ & $17.2 \mathrm{a}$ & $35.42 a$ & $34.20 \mathrm{a}$ & $614.75 a$ & $588.90 \mathrm{a}$ & $26.00 a$ & $32.50 \mathrm{a}$ & $8875 a$ & $10961 a$ \\
\hline Urea & $17.5 a$ & $17.2 \mathrm{a}$ & $34.93 a$ & $34.15 a$ & $611.80 a$ & $585.55 a$ & $25.10 \mathrm{a}$ & $31.35 a$ & $8215 b$ & $10582 a$ \\
\hline$P \geq 0.05$ & 0.40 & 0.50 & 1.03 & 1.10 & 22.70 & 23.85 & 0.95 & 1.35 & 380.0 & 648.7 \\
\hline \multicolumn{11}{|l|}{ Time } \\
\hline Sowing & $17.5 a$ & $17.2 \mathrm{a}$ & $35.01 a$ & $34.45 a$ & $612.40 a$ & $590.60 a$ & $26.25 a$ & $31.75 a$ & $8720 a$ & $10752 a$ \\
\hline Side dressing & $17.4 a$ & $17.2 \mathrm{a}$ & $35.17 a$ & $34.15 a$ & $613.10 a$ & $587.70 a$ & $25.50 \mathrm{a}$ & $32.55 a$ & $8620 a$ & $10840 a$ \\
\hline$P \geq 0.05$ & 0.30 & 0.30 & 0.70 & 0.75 & 15.45 & 16.20 & 0.80 & 0.85 & 258.0 & 441.2 \\
\hline \multicolumn{11}{|l|}{ Rates $\left(\mathrm{kg} \mathrm{ha}^{-1}\right)$} \\
\hline 0 & 17.6 & 17.1 & 33.24 & 33.90 & 585.35 & 581.10 & 24.35 & 30.00 & 6880 & 8630 \\
\hline 50 & 17.6 & 17.1 & 35.50 & 34.40 & 622.90 & 586.55 & 25.12 & 32.30 & 8023 & 10302 \\
\hline 100 & 17.3 & 17.2 & 35.00 & 34.20 & 606.30 & 586.90 & 25.90 & 32.35 & 8916 & 11385 \\
\hline 150 & 17.3 & 17.2 & 35.50 & 34.55 & 621.60 & 592.90 & 26.85 & 32.55 & 9563 & 11880 \\
\hline 200 & 17.3 & 17.4 & 36.22 & 34.40 & 627.64 & 598.40 & 27.07 & 33.55 & 9962 & 11786 \\
\hline Means & 17.5 & 17.2 & 35.09 & 34.28 & 612.75 & 589.15 & 25.88 & 32.15 & 8670 & 10796 \\
\hline CV (\%) & 3.65 & 4.75 & 5.50 & 6.10 & 6.95 & 7.60 & 6.50 & 6.60 & 8.20 & 11.30 \\
\hline$F$ test & ns & ns & $*(1)$ & ns & ${ }^{*}(2)$ & ns & $*(3)$ & $*(4)$ & ${ }^{*}(5)$ & $*(6)$ \\
\hline
\end{tabular}

Ammonium sulphate nitrate (ASN) with nitrification inhibitor (ASN+l), ammonium sulphate (AS). Coefficient of variation (CV) from the variance analyses, grain yield (GY). Minimum significant difference $(P \geq 0.05)$ by the Tukey test. Means followed by similar

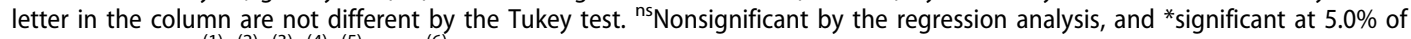
probability level. (1), (2), (3), (4), (5), and (6) are about the equations below:

(1) $\hat{y}=33.893+0.012 N\left(R^{2}=0.71\right)(2) \hat{y}=596.093+0.167 N\left(R^{2}=0.60\right)$

(3) $\hat{y}=24.414+0.014 N\left(R^{2}=0.97\right)(4) \hat{y}=30.671+0.015 N\left(R^{2}=0.80\right)$

(5) $\hat{y}=6880.24+25.323 \mathrm{~N}-0.0495 N^{2}\left(R^{2}=0.99\right.$ and $\left.P M=256 \mathrm{~kg} \mathrm{Nha}^{-1}\right)$

(6) $\hat{y}=8629.805+39.335 N-0.118 N^{2}\left(R^{2}=0.93\right.$ and $\left.P M=167 \mathrm{~kg} \mathrm{Nha}^{-1}\right)$ 
In both growing seasons, the $\mathrm{N}$ sources and application time did not affect the biomass of 100 grains (Table 2). Similarly, results were reported by Souza et al. (2011), and Kappes et al. (2009), Lourente et al. (2007), Goes et al. (2013) and Kappes et al. (2014) when all of them tested urea and AS, as well as Souza and Soratto (2006) who also applied urea and nitrate ammonium sulfate (NAS) as the inhibitor of nitrification.

Similarly, no matters the fertilizer source, Silva et al. (2005a), Silva et al. (2006), Souza et al. (2011) and Kappes et al. (2014) reported that the increases in the $\mathrm{N}$ rates linearly increased the 100 grains biomass (Table 2). Souza and Soratto (2006) and Gomes et al. (2007), however, did not find significant effects of N rates in the grain biomass. In the literature, these responses are discrepant because genetic and environmental factors can have influence on the results (Baligar, Fageria, and He 2001).

\section{Crop yield}

The time of $\mathrm{N}$ application significantly did not differ as to crop yield (Table 2) indicating that the $\mathrm{N}$ fertilization can be done on the sowing time or side dressing in the maize under NTS. Silva et al. (2005b), Santos et al. (2010) and Pissinati et al. (2013) also did not find significant differences in maize crop yield when they compared the sowing application or side dressing; however, Silva et al. (2005a) reported higher grain yield (GY) when the half rate was applied in the sowing and the rest in topdressing (from 4 to 6 or 8 to 10 leaves) or the whole $\mathrm{N}$ was topdressing applied (from 4 to 6 leaves).

Thus, under the edaphoclimatic conditions in the current experiment, the anticipation of the fertilization in the sowing time is reliable, although cropping maize in NTS and supplementary irrigation was done in a period with high rainfall (Figure 1) and the soil had water excess. Making the anticipation cannot be a general decision because in rainy years the responses can be different (Wolschick, Carlesso, and Jadoski 2003). Based on Santos et al. (2010), in conjunction with the soil management and time of N application, the physical, chemical and biological characteristics of the soil as well as the weather conditions have influence in the available $\mathrm{N}$ to the plants. The mean yield from the control harvested in first growing season was $6,880 \mathrm{~kg} \mathrm{ha}^{-1}$ and in the second was $8,630 \mathrm{~kg} \mathrm{ha}^{-1}$ (Table 2) signaling a residual fertilizer effect from the crop which indicates a higher rate in the second growing season in conjunction with the weather conditions in both (Figure 1).

Concerning the effects of the N sources on the GY, despite the sources had similar productivity in both growing seasons, in the first there was significant difference when the application of the ASN+1 and AS had grain yield higher than urea (Table 2). This result disagree from Souza et al. (2011) and Souza, Buzetti, and Moreira (2016) when they studied the same treatments in the same region and soil, where they did not find responses of N sources in the grain yield (GY). Schiavinatti et al. (2011) and Souza, Buzetti, and Moreira (2016) studying the same sources in the same soil and climatic conditions found significant effect of $\mathrm{N}$ sources in the GY (Lara Cabezas, Kondörfer, and Motta 1997). Lara Cabezas et al. (2005) had higher GY using AS than urea despite of the time of the $\mathrm{N}$ application (pre-sowing or side dressing). Probably, the AS was faster than urea in the $\mathrm{N}$ immobilized-mineralized, and consequently there was more $\mathrm{N}$ assimilation by the crop. Furthermore, the AS is also source of N and S (22\%).

Based on quadratic models fit with the $\mathrm{N}$ rates, the increment of the $\mathrm{N}$ rates had positive influence on the GY in the respective growing seasons. The higher yield in every growing season was 10,120 and $11,915 \mathrm{~kg} \mathrm{ha}^{-1}$ of grain with the estimates of $\mathrm{N}$ at 256 and $167 \mathrm{~kg} \mathrm{ha}^{-1}$, respectively (Table 2). Similar productivities were reported by Araújo et al. (2004) when they applied at $240 \mathrm{~kg} \mathrm{~N}^{-1}$ and found $11,203 \mathrm{~kg} \mathrm{ha}^{-1}$. Linear responses in productivity because of the $\mathrm{N}$ rates were reported by Duete et al. (2008). We highlighted that adequate $\mathrm{N}$ rate to obtain high crop yields depends on the area story, genetic material, soil management system and previous crops.

\section{Conclusions}

Adequate use of source $\mathrm{N}$ fertilizer for maize increases the yield and the economic return. The sources of $\mathrm{N}$ had similar effects in most of the agronomic characteristics of maize under no-tillage system (NTS), unlike the foliar N contents and grain productivity in the first growing season. The 
early $\mathrm{N}$ fertilization at maize sowing under no-tillage system (NTS) was significant as well as the side dressing application. The increase of $\mathrm{N}$ rates, regardless of source, affected positively the foliar $\mathrm{N}$ contents, the plant height $(\mathrm{PH})$ and the biomass of 100 grains. No matter the $\mathrm{N}$ sources and the application time, the highest GY under NTS was achieved with rates at the $\mathrm{N}$ threshold at $150 \mathrm{~kg} \mathrm{ha}^{-1}$.

\section{Funding}

We are grateful to the FAPESP for the financial support (Process FAPESP 2006/04277-3) and the scholarship to the first author.

\section{References}

Araújo, L. A. N., M. E. Ferreira, and M. C. P. Cruz. 2004. Nitrogen fertilization to corn. Pesquisa Agropecuária Brasileira 39:771-777.

Baligar, V. C., N. K. Fageria, and Z. L. He. 2001. Nutrient use efficiency in plants. Communications in Soil Science and Plant Analysis 32:921-50. doi:10.1081/CSS-100104098.

Cantarella, H., B. van Raij, and C. E. O. Camargo. 1997. Recommendations liming and fertilization for the São Paulo State. In Cereals, eds. B. van Raij, H. Cantarella, J. A. Quaggio, and A. M. C. Furlani, 43-71. Campinas, Brazil: IAC.

Duete, R. R. C., T. Muraoka, E. C. Silva, P. C. O. Trivelin, and E. J. Ambrosano. 2008. Nitrogen fertilization management and nitrogen $(15 \mathrm{~N})$ utilization by corn crop in Red Latosol. Revista Brasileira de Ciência do Solo 32:161-71. doi:10.1590/S0100-06832008000100016.

EMBRAPA (Empresa Brasileira de Pesquisa Agropecuária). 2006. Brazilian system of soil classification. Londrina, Brazil: Embrapa Soils.

Fageria, N. K. 2014. Nitrogen management in crop production. Boca Raton, FL: CRC Press.

Fageria, N. K., A. Moreira, and A. M. Coelho. 2011. Yield and yield components of upland rice as influenced by nitrogen sources. Journal of Plant Nutrition 34:261-70.

Figueiredo, C. C., D. V. S. Resck, A. C. Gomes, and S. Urquiaga. 2005. Management systems on nitrogen absorption by corn in an Oxisol in the Cerrado. Pesquisa Agropecuária Brasileira 40:279-87. doi:10.1590/S0100204X2005000300012.

Goes, R. J., R. A. F. Rodrigues, A. T. Takasu, and O. Arf. 2013. Agronomic characteristics and yield of maize under different sources and doses of top-dressed nitrogen application at winter. Revista Brasileira De Milho E Sorgo 12:250-59. doi:10.18512/1980-6477/rbms.v12n3p250-259.

Gomes, R. F., A. G. Silva, R. L. Assis, and F. R. Pires. 2007. Effect of doses and timing of nitrogen application on agronomical traits of no-till corn. Revista Brasileira de Ciência do Solo 31:931-38. doi:10.1590/S010006832007000500010 .

IFA (International Fertilizer Industry Association). 2014. The nitrification inhibitor DMPP (ENTEC ${ }^{\circledR}$ for use in agricultural crops. Paris, France: IFA.

Kappes, C., O. Arf, E. A. Dal Bem, J. R. Portugal, and A. R. Gonzaga. 2014. Side-dressing nitrogen management in maize crop in no-till system. Revista Brasileira de Milho e Sorgo 13:201-17. doi:10.18512/1980-6477/rbms. v13n2p201-217.

Kappes, C., M. A. C. Carvalho, O. M. Yamashita, and J. A. N. Silva. 2009. Nitrogen influence on double-cropped corn yield after soybean. Pesquisa Agropecuária Tropical 39:251-59.

Lara Cabezas, W. A. R., M. R. Arruda, H. Cantarella, V. Pauletti, P. C. O. Trivelin, and J. A. Bendassolli. 2005. Nitrogen immobilization of urea and ammonium sulphate applied to maize before planting and as top-dressing in a no-till system. Revista Brasileira de Ciência do Solo 29:215-26.

Lara Cabezas, W. A. R., G. H. Kondörfer, and S. A. Motta. 1997. NH3-N volatilization in corn crop: Effect of irrigation and partial substitution of urea by ammonium sulphate. Revista Brasileira de Ciência do Solo 21:481-87.

Lourente, E. R. P., R. Ontocelli, L. C. F. Souza, M. C. Gonçalves, M. E. Marchetti, and E. T. Rodrigues. 2007. Antecedent crops, doses and sources of nitrogen on yield compounds of corn. Acta Scientiarum Agronomy 29:55-61.

Pissinati, A., M. A. Oliveira, A. Pissinatti, and A. Moreira. 2013. Management and cost of urea application in maize grown in northern Paraná State, Brazil. Revista de Ciências Agrárias 56:235-41.

Pöttker, D., and S. Wiethölter. 2004. Timing and methods of nitrogen application for corn under no-tillage. Ciência Rural 34:1015-20.

Raij, B., J. C. van, A. H. Cantarella, and J. C. Quaggio. 2001. Chemical analysis to evaluate the tropical soils fertility. Campinas, Brazil: IAC.

Sangoi, L., P. R. Ernani, and P. R. F. Silva. 2007. Corn response to nitrogen fertilization timing in two tillage systems in a soil with high organic matter content. Revista Brasileira de Ciência do Solo 31:507-17. doi:10.1590/S010006832007000300011. 
Santos, M. M., J. C. C. Galvão, G. V. Miranda, L. R. Ferreira, A. Vaz de Melo, and A. Fontanetti. 2007. Space between lines and nitrogen fertilizer in corn culture. Acta Scientiarum Agronomy 29:527-33.

Santos, M. M., J. C. C. Galvão, I. R. Silva, G. V. Miranda, and F. L. Finger. 2010. Nitrogen sidedressing and molybdenum application to untilled corn and nitrogen $(15 \mathrm{~N})$ allocation in the plant. Revista Brasileira de Ciências do Solo 34:1185-94. doi:10.1590/S0100-06832010000400018.

Schiavinatti, A. F., M. Andreotti, C. G. S. Benett, C. M. Paris, B. N. Lodo, and S. Buzetti. 2011. Influence of nitrogen sources and application methods on yield and productivity components of irrigated corn in savannah soil. Bragantia 70:925-30. doi:10.1590/S0006-87052011000400027.

Silva, E. C., S. Buzetti, G. L. Guimarães, E. Lazarini, and M. E. Sá. 2005a. Rates and timing of nitrogen application in corn under no-tillage on a Red Latosol. Revista Brasileira de Ciência do Solo 29:353-62. doi:10.1590/S010006832005000300005.

Silva, E. C., S. M. Ferreira, G. P. Silva, R. L. Assis, and G. L. Guimarães. 2005b. Timing and methods of nitrogen application to no-tillage corn on Cerrado soil. Revista Brasileira de Ciência do Solo 29:725-33. doi:10.1590/S010006832005000500008.

Silva, E. C., T. Muraoka, S. Buzetti, and P. C. O. Trivelin. 2006. Nitrogen management in corn under no-tillage with different cover crops in a Rhodic Hapludox soil. Pesquisa Agropecuária Brasileira 41:477-86. doi:10.1590/S0100204X2006000300015.

Souza, E. F. C., and R. P. Soratto. 2006. Effect of sidedressing nitrogen sources and doses on out-of season corn in no-tillage system. Revista Brasileira de Milho e Sorgo 5:395-405. doi:10.18512/1980-6477/rbms.v5n3p395-405.

Souza, J. A., S. Buzetti, and A. Moreira. 2016. Economic analysis of source and rates nitrogen fertilization in second corn crop in no-till system. Revista De Ciências Agrárias 59:235-41.

Souza, J. A., S. Buzetti, M. C. M. Teixeira Filho, M. Andreotti, M. Eustáquio De Sá, and O. Arf. 2011. Nitrogen fertilization on second crop corn in no till irrigated. Bragantia 70:447-54. doi:10.1590/S0006-87052011000200028.

Wolschick, D. R., M. T. P. Carlesso, and S. O. Jadoski. 2003. Nitrogen application on maize cultivated under no-tillage system in a year with normal precipitation and with 'El Niño'. Revista Brasileira de Ciência do Solo 27:461-68. doi:10.1590/S0100-06832003000300008. 